\title{
Calpain inhibitors reduce the cornified cell envelope formation by inhibiting proteolytic processing of transglutaminase 1
}

\author{
Soo-Youl Kim ${ }^{1}$ and Chang-Dae Bae ${ }^{2,3}$ \\ 1 Laboratory of Skin Biology, NIAMS, NIH, Bethesda, \\ MD 20892-2755, U.S.A \\ 2 Department of Biochemistry, College of Medicine, Hallym University, \\ Chunchon, Kangwondo 200-702, Korea \\ 3 Corresponding author: Fax, 82-331-285-0328; \\ E-mail, cdbae@sun.hallym.ac.kr
}

Accepted 2 December 1998

The abbreviations: CE, cornified cell envelope; NHEK, normal human epidermal keratinocytes; TGase(s), transglutaminase(s); TGase 1, the membrane-associated TGase or TGase K or Type I keratinocyte TGase; TGase 2, the ubiquitous tissue TGase or TGase C or Type II liver TGase; TGase 3, pro-TGase E or epidermal TGase

\author{
Introduction
}

Transglutaminase (TGase, EC 2.3.2.13) is a calcium dependent enzyme that catalyzes the formation of covalent $\varepsilon$-( $\gamma$-glutamyl)lysine cross-links in proteins (Folk and Finlayson, 1977). In the mammalian epidermis, there are three different TGases expressed. TGase 1 covers the most abundant messages among TGases in the epidermis and expression is observed from the basal layer to the top of the cornified envelope building a scaffold of barrier (Rice and Green, 1977; Thacher and Rice, 1985; Kim et al., 1994; Kim et al., 1995). We revealed that processing of TGase 1 is very specific, but by unknown protease(s) giving 20 times higher activity than intact form (Kim et al., 1995; Steinert et al., 1996). TGase 2 is an ubiquitous enzyme expressed in every cells and tissues (lkura et al., 1988; Gentile et al., 1991). In the human epidermis, TGase 2 is expressed mostly in the supra basal layer and dermal layer which suggests it might be related with cell proliferation and extracellular matrix formation (Aeschilimann and Paulsson, 1991). Although many studies have revealed that TGase 2 can be related to apoptosis in neuronal tissues (Fesus et al., 1987), the physiological role of this enzyme is uncertain due to its ubiquitous expression and dual function as a GTPase enzyme (Nakaoka et al., 1994). Interestingly, only TGase 2 loses TGase activity among the TGase family by the action of proteases including calpain I (Zhang et al. 1998). This could be related with an in vitro experiment that demonstrated the increase of GTPase activity by specific truncation (Lai et al., 1996). TGase 3 is expressed on the upper granular layer to complete CE formation (Chung and Folk, 1972; Negi et al., 1985; Kim et al., 1990). Proteolysis of TGase 3 is involved in the active form which showed a 60 times higher activity than the pre-form (Kim et al., 1990). Though TGase 1 and 3 should require proteolysis for active catalysis, the specific protease which activates these TGases has not been reported to date. During terminal epidermal differentiation, proteolytic processing contributes to the increasing activity of epidermal transglutaminases (TGase 1 and 3) and also covalently cross-links precursor proteins to form CE in horney layers (Steinert and Marekov, 1995; Steinert et al., 1998). Noting this process, we explored the protease system which should be related to calcium dependent differentiation.

Calpain (EC 3.4.22.17) is a calcium dependent cysteine proteinase and ubiquitously distributed in various mammalian cells (Suzuki et al., 1987). Calpain forms a family consisting of at least six distinct members (Sorimachi et al., 1989, 1993, 1994). The family can be divided into

Keywords: calpain inhibitor, transglutaminase 1, cornified envelope 
two groups on the basis of distribution - ubiquitous and tissue specific. However, our current knowledge of the biochemical properties of calpain applies mostly to the ubiquitous isozymes, calpain I ( $\mu$-calpain) and II (mcalpain). All the ubiquitous calpain isozymes are hetero dimers consisting of one large subunit and one small subunit. The small regulatory subunit carrying another calcium binding domain is common to both the isozymes (Sorimachi et al., 1994), though their amounts vary from one tissue to another. Both share similar biochemical characteristics except for the calcium concentration required for activation in vitro; calpain I is activated in the presence of micromolar levels of calcium whereas calpain II requires millimolar levels (Suzuki et al., 1987). Calpain I and II are known to be present in human skin and have been presumed to participate in various cellular functions mediated by calcium (Miyachi et al., 1986). One report demonstrated that platelet factor XIIla (TGase) could be activated by calpain (Ando et al., 1987). However, there is no direct evidence for the contribution of calpains to processes of TGase 1 and 3 in the epidermis. Here we report that protease inhibitor studies revealed that calpain inhibitor specifically blocked the CE formation by inhibiting TGase 1 activation.

\section{Materials and Methods}

\section{Conditions for TGase assays}

A modified TGase assay method was used to determine enzyme activity by the measurement of the incorporation of $\left[1,4{ }^{14} \mathrm{C}\right]$-putrescine into succinylated casein (Folk and Chung, 1985). The samples were mixed in an reaction mixture $(0.5 \mathrm{ml})$ containing $0.1 \mathrm{M}$ Tris-acetate $(\mathrm{pH} 7.5)$, $1 \%$ succinylated casein, $1 \mathrm{mM}$ EDTA, $10 \mathrm{mM} \mathrm{CaCl}_{2}, 0.5 \%$ lubrol PX, 5 mM DTT, $0.15 \mathrm{M} \mathrm{NaCl}$ (Sigma Chemical Co, St. Louis, MO, U.S.A.) and $0.5 \mathrm{mCi}$ of $\left[{ }^{14} \mathrm{C}\right]$ putrescine (118 Ci/mole) (Dupont-New England Nuclear, Wilmington, DE, U.S.A.). Following incubation at $37^{\circ} \mathrm{C}$ for $1 \mathrm{~h}$, the reaction was terminated by the addition of $4.5 \mathrm{ml}$ of cold $\left(4^{\circ} \mathrm{C}\right) 7.5 \%$ TCA. The TCA-insoluble precipitates were collected on GF/A glass fiber filters (Whatman, England) washed with cold $5 \%$ TCA, dried and then counted.

Figure 1. TGase 1 activation correlated with insoluble cross-linked CE formation during calcium induced differentiation of NHEK. NHEK cells were grown under low $(0.05 \mathrm{mM})$ and high (1.2 mM) calcium conditions to confluence. A) The cells were harvested and seperated on the Mono-Q HPLC column using a NaCl gradient after 5 days (see 'Materials and Methods'). The arrow head shows highly active processed TGase 1 (Kim et al., 1995). B) Each value represents the highly active TGase peak from panel A at numbered days after induced differentiation under high calcium conditions. C) The CE was purifed and measured for relative turbidity using a spectorphotometer at 310 $\mathrm{nm}$ at numbered days after induced differentiation under high calcium conditions.
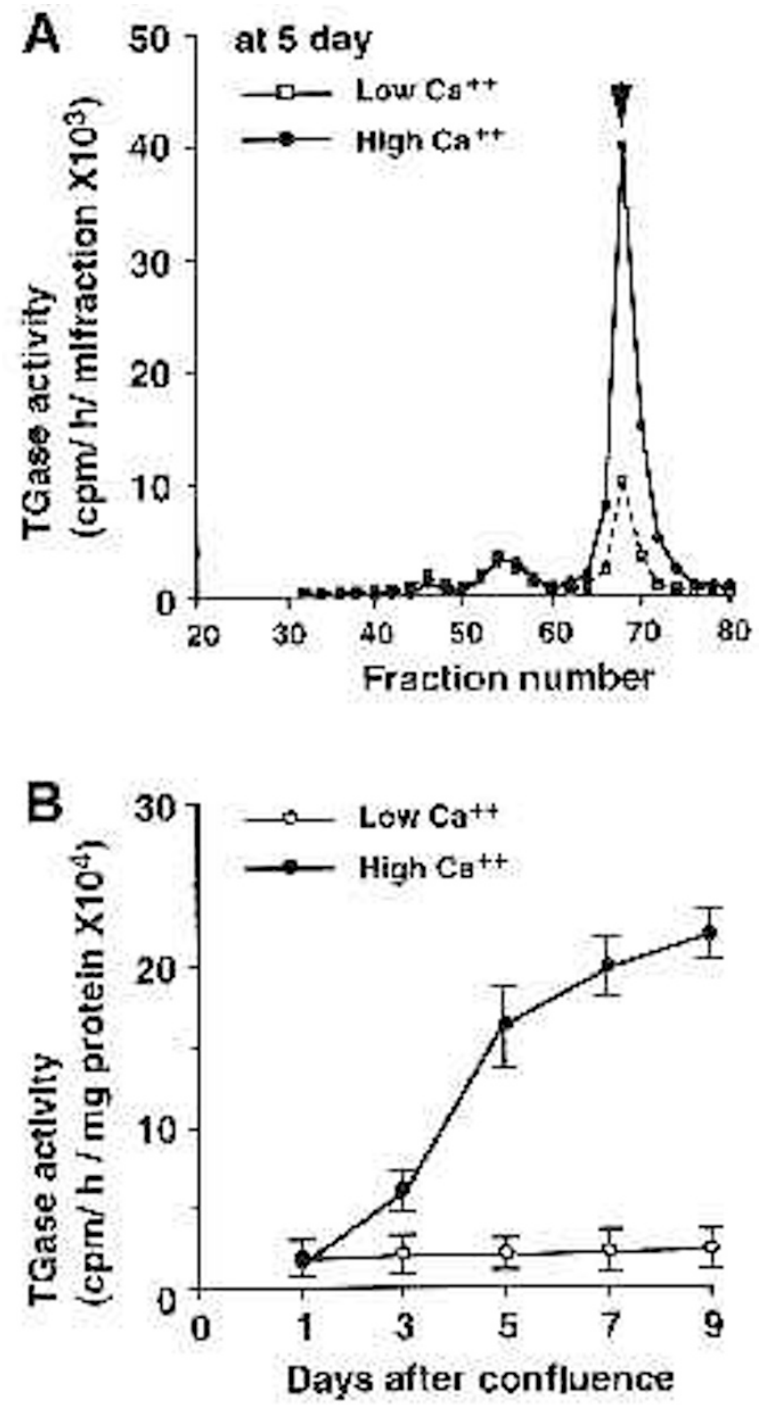

C

gt $310 \mathrm{~nm}$

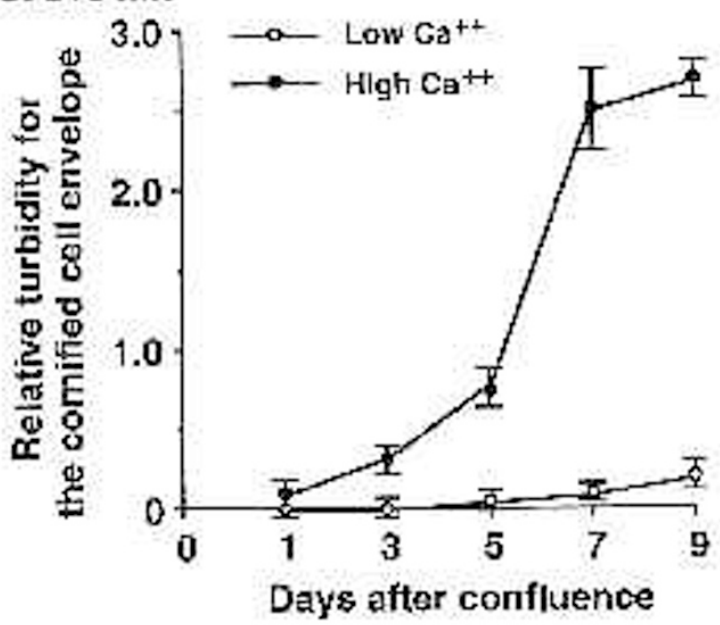




\section{Protease inhibitors treatment of the NHEK cells}

Normal human epidermal keratinocytes (NHEK, Clonetics, San Diego, CA, U.S.A.) were grown to confluency in a medium containing $0.05 \mathrm{mM} \mathrm{CaCl}_{2}$ as recommended by the manufacturer. At $100 \%$ confluency, the calcium level was raised to $1.2 \mathrm{mM}$ for the calcium induced differentiation and the cells were treated with various protease inhibitors in a concentration range of $0.5 \mu \mathrm{M}$ to $0.5 \mathrm{mM}$ including aprotinin, leupeptin (Acetyl-leu-leu-arg-al) and calpain I inhibitor (N-acetyl-leu-leu-norleucinal) (BoehringerMannheim Co, Indianapolis, IN, U.S.A.). Following 1, 3, 5,7 and 9 days of treatment, the cells were harvested by scraping, sonicated, and incubated for $15 \mathrm{~min}$ at $4^{\circ} \mathrm{C}$ in a buffer containing $0.1 \mathrm{M}$ Tris-acetate, $0.1 \%$ Triton $\mathrm{X}$ $1000.15 \mathrm{M} \mathrm{NaCl}, 1 \mathrm{mM}$ and EDTA (TTBS) $\left(4 \times 10^{8} \mathrm{cells} /\right.$ $\mathrm{ml}$ ). The lysate was clarified by centrifugation at 10,000 $g$ for $20 \mathrm{~min}$ at $4^{\circ} \mathrm{C}$ to obtain the total extraction of the cells (Steinert et al., 1996). After centrifugation at 10,000 $g$ for $10 \mathrm{~min}$, the total fraction was subjected to chromatography on a $0.5 \times 5 \mathrm{~cm}$ mono-Q HPLC column using $50 \mathrm{ml}$ of a 0 to $0.5 \mathrm{M} \mathrm{NaCl}$ linear gradient $(0.5 \mathrm{ml} / \mathrm{min}$, $0.5 \mathrm{ml}$ fractions) (Kim et al., 1990). Aliquots from every other fraction were used for TGase activity measurements. Three peaks of activity were identified (panel A of Figure 1 ), which were then separately pooled. The main peak of TGase activity in each treatment group was measured and then normalized by protein amount throughout the treatment days (panel B of Figure 1), which corresponded to the active processed TGase 1 (Kim et al., 1995). The immunoprecipitation was performed using polyclonal antiTGase1, immobilized to protein G-agarose as described before (Kim et al., 1994). The immunoprecipitates were used for gel electrophoresis (panel D of Figure 2).

\section{Preparation of CE from cultured human keratinocyte}

We used a calcium-induced differentiation model of
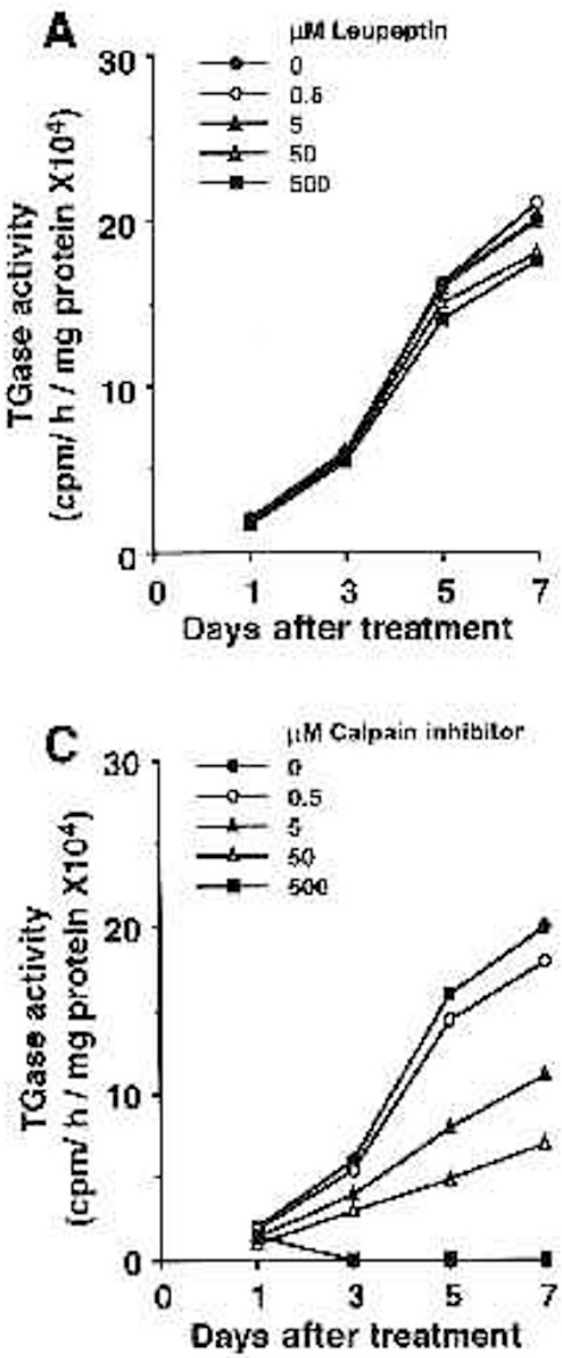
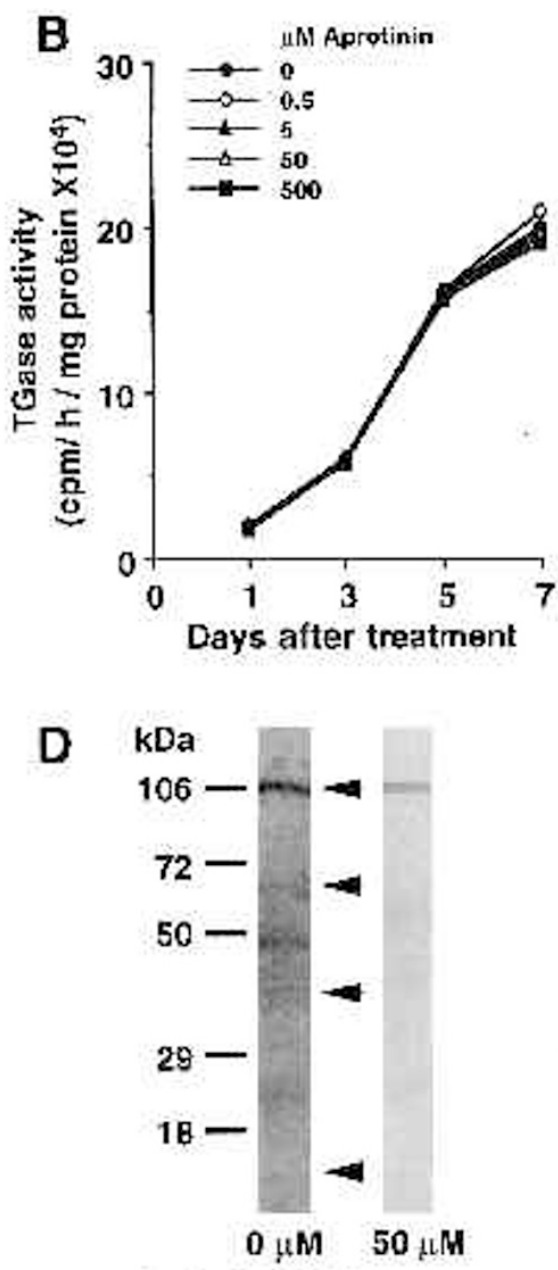

Calpain Inhlbltor treatment at 5 day
Figure 2. Dose-dependent inhibitory effects of TGase activity using various protease inhibitors on calcium induced differentiating NHEK cells. Leupeptin (A), aprotinin (B), and calpain I inhibitor (C) were treated in the culture media seperately in concentrantions ranging from 0.5 to $500 \mu \mathrm{M}$. (D) The coomassie staining of immunoprecipitation using anti-TGase 1 with or without treatment with calpain inhibitor $(50 \mu \mathrm{M})$ was performed. Without treatment, multiple processed bands at $67,33,10 \mathrm{kDa}$ including a $106 \mathrm{kDa}$ intact band (arrow heads) were noticed as reported (Kim et al., 1995) while no processed form was observed during treatment. 
keratinocytes as described, (Kim et al., 1995) was employed. The peptides inhibitors were added to the media at several different concentrations from $50 \mu \mathrm{M}$ to $50 \mathrm{mM}$. At 1, 3, 5, 7 and 9 days of treatment, the cultured keratinocytes were harvested by scraper and the CE was purified by the established method (Schimidt et al., 1988). The purified CE was dissolved in $1 \mathrm{ml}$ TTBS buffer $/ 1.6 \times 10^{7}$ cells and sonicated twice for $30 \mathrm{sec}$ at $70-90$ watts. Turbidity of the insoluble CE at $310 \mathrm{~nm}$ was measured.

\section{Results and Discussion}

\section{The proteolytic activation of increased TGase 1 expression is responsible for insoluble CE formation during calcium induced differentiation}

NHEK cells can be differentiated under from low calcium $(0.05 \mathrm{mM})$ to high calcium $(1.2 \mathrm{mM})$ culture conditions. During this morphophysiological change, many structural proteins alter the expression. Keratin 5 and 14 expression in the proliferating NHEK cells switch to keratin 1 and 10 in differentiating cells (Fuchs and Green, 1980, 1981). Also terminal differentiation related proteins start being expressed to build a scaffold of barrier structures such as loricrin, filaggrin, small proline rich proteins, envoplakin, elafin, and involucrin (Steinert and Marekov, 1995). These structural proteins form envelopes in a highly ordered manner and finally are cross-linked by TGase (Steinert et al., 1998). Though there are three TGase isotypes in the human skin, over $90 \%$ of TGase messages are TGase 1 in cultured NHEK cells under high calcium conditions (Steinert et al., 1996). We showed that TGase activity is closely related with CE formation. The profile of TGase activity in panel $A$ of Figure 1 showed that the most TGase activity after calcium induced differentiation corresponds to processed TGase 1 (Kim et al., 1995). This activity peak was increased up to 10 folds after 7 day culture in high calcium compared to low calcium conditions (panel $B$ of Figure 1). However, between 3 and 5 days, TGase 1 activity exponentially increased. Interestingly the insoluble CE exponentially increased up to 27 folds between 5 and 7 days under high calcium conditions (panel $C$ of Figure 1). This suggests that TGase 1 activity might increase 24 to $48 \mathrm{~h}$ prior to the increase of CE.

\section{Calpain I inhibitor reduced TGase 1 activity by inhibiting TGase 1 processing in differentiating NHEK cells}

Our previous study showed that proteolytic activation was required to obtain high functional activity of TGase 1 in vitro or in NHEK cells (Kim et al., 1995; Kim et al., 1996). Hence, we employed the several protease inhibitor treatments on the NHEK cells during the calcium induced differentiation. Leupeptin was selected for inhibiting serine thiol proteases such as trypsin, plasmin, proteinase $\mathrm{K}$, kallikrein, papain, thrombin, and cathepsin $A$ and $B$. Apro-tinin, a known as serine protease inhibitor, was selected to inhibit plasmin, kallikrein, trypsin, and chymotrypsin. N-Acetyl-Leu-Leu-norleucinal (calpain I inhibitor) was selected to inhibit calpain I and II, since there was a report of calpain I and II expression in skin (Miyachi et al., 1986). Though calpain I inhibitor was developed for strong competitive inhibitor of the calcium dependent neutral cysteine protease calpain I and II, it can also be a strong inhibitor of papain and cathepsin B and L. Panel A of Figure 2 shows that 0.5 $\mathrm{mM}$ leupeptin treatment reduced by only $10 \%$ TGase 1
A

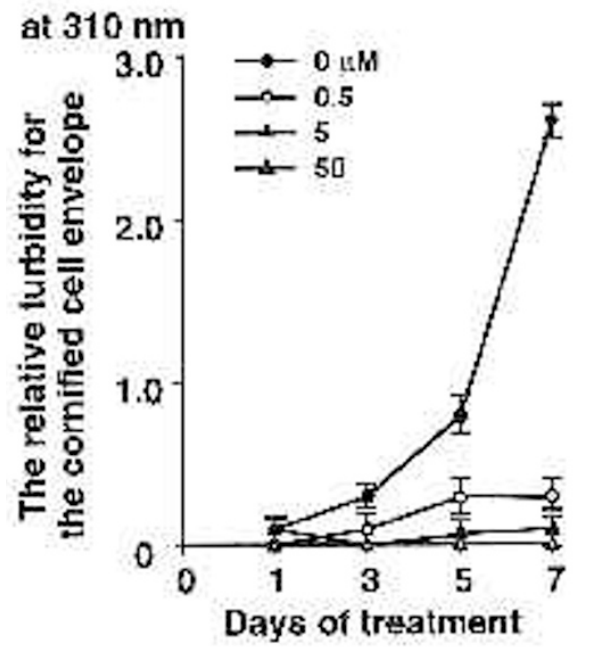

B

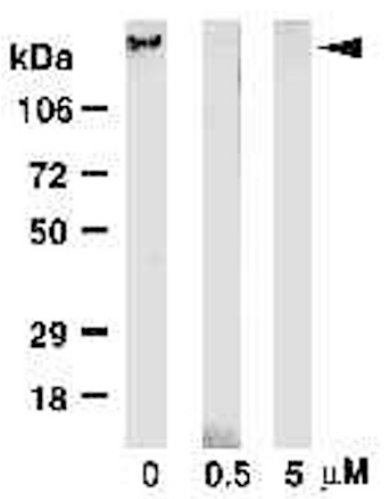

Calpain inhibitor treatinent at 5 day
Figure 3. The inhibitory effect of CE formation in NHEK cells by treatment with calpain I inhibitor. (A) The inhibitor was in the concentration range of 0.5 to $50 \mu \mathrm{M}$. CE was purified and measured at $310 \mathrm{~nm}$ after inhibitor treatment under high calcium conditions (details in 'Materials and Methods'). (B) Coomassie staining of purified CE was shown mostly in the stacking gel due to its high molecular weight (arrow head) after 10\% tris-glycine SDS-polyacrylamide gel elctrophoresis. 
activity while panel $\mathrm{C}$ shows dramatic decrease of TGase 1 activity by almost $100 \%$ on day 3 of treatment with calpain I inhibitor. We selected samples at day 5 from control and $50 \mu \mathrm{M}$ calpain I inhibitor treated cells for immunoprecipitations using anti-TGase 1 (panel D of Figure 2). This gave processed TGase 1 bands at 67, 33, $10 \mathrm{kDa}$ including intact $106 \mathrm{kDa}$ (arrow heads) from the non-treated sample while a calpain I inhibitor treated sample gave only the intact form of TGase 1. Even though leupeptin and aprotinin did not inhibit TGase 1 activity, there is a possibility that these inhibitors were more unstable than calpain inhibitors.

\section{Calpain I inhibitor reduced insoluble CE formation}

Insoluble CE was purified from the same experimental sets of NHEK cells as panel C of Figure 2. Surprisingly Calpain I inhibitor was very effective in preventing the formation of insoluble CE (panel A of Figure 3). At day $7,0.5 \mu \mathrm{M}$ calpain I inhibitor inhibited about $90 \%$ of CE formation. This strong efficacy might be due to the small molecular weight and non-charged molecular structure of the calpain I inhibitor. The purified insoluble CE from control, 0.5 and $5 \mu \mathrm{M}$ calpain I inhibitor treated group was run on a $10 \%$ tricine-SDS acrylamide gel (panel B of Figure 3). The CE could not penetrate into the stacking gel due to highly cross-linked polymers (arrow head). This was reduced to the level of production under low calcium conditions by $5 \mathrm{mM}$ calpain inhibitor treatment. This result suggests that the differentiation rate might be closely related to functional calpain content in keratino-cytes (Miyachi et al., 1986). In the inhibitor treatment of cultured cells, we observed no side effects such as cell detachment or apoptosis (data not shown). Therefore, calpain inhibitors might be useful in reducing insoluble corneum in hyperkeratotic skin lesions. However, there are obvious limitations to the use of calpain inhibitor I both as a pharmacological tool and in medicine, since its selectivity is lower than in vivo inhibitor calpastatin (Wang, 1990). Further study will determine the mechanism of how and when calpain recognizes TGase 1 as an endogenous substrate.

\section{References}

Aeschlimann, D. and Paulsson, M. (1991) Cross-linking of laminin-nidogen complexes by tissue transglutaminase: A novel mechanism for basement membrane stabilization. $J$. Biol. Chem. 266: 15308-15317

Ando, Y., Imamura, S., Yamagata, Y., Kitahara, A., Saji, H., Murachi, T.and Kannagi, R. (1987) Platelet factor XIII is activated by calpain. Biochem. Biophys. Res. Commun. 144: 484-490

Chung, S.-I. and Folk, J. E. (1972) Transglutaminase from hair follicle of guinea pig. Proc. Natl. Acad. Sci. USA 69: 303-307

Fesus, L, Thomazy, V. and Falus A. (1987) Induction and activation of tissue transglutaminase during programmed cell death. FEBS Lett. 224: 104-108
Folk, J. E. and Chung, S.-I. (1985) Transglutaminases. Methods Enzymol. 113: 358-375 Folk, J. E. and Finayson, J. S.(1977) The epsilon-(gamma-glutamyl)lysine crosslink and the catalytic role of transglutaminases. Adv. Protein Chem. 31: 1-133

Fuchs, E. and Green, H. (1980) Changes in keratin gene expression during terminal differentiation of the keratinocyte. Cell 19: 1033-1042

Fuchs, E. and Green, H. (1981) Regulation of terminal differentiation of cultured human keratinocytes by vitamin A. Cell 25: 617-625

Gentile, V., Satdak, M., Chiocca, A., Akande, O., Birckbichler, P. J., Lee, K.-N., Stein, J. P. and Davies, P. J. (1991) Isolation and characterization of CDNA clones to mouse macrophage and human endothelial cell tissue transglutaminases. J. Biol. Chem. 266: 478-483

Ikura, K., Nasu, T., Yokota, H., Tsuchiya, Y., Sasaki, R. and Chiva, H. (1988) Amino acid sequence of guinea pig liver transglutaminase from its cDNA sequence. Biochemistry 27: $2898-2905$

Kim, S.-Y., Chung, S.-I. and Steinert, P. M. (1995) Highly active soluble processed forms of the transglutaminase 1 enzyme in epidermal kera-tinocytes. J. Biol. Chem. 270: 18026-18035

Kim, S.-Y., Kim, I.-G., Chung, S.-I. and Steinert, P. M. (1994) The structure of the transglutaminase 1 enzyme. J. Biol. Chem. 269: 27979-27986

Kim, H. C., Lewis, M. S., Gorman, J. J., Park, S.-C., Girard, J. E., Folk, J. E. and Chung, S.-I. (1990) Protransglutaminase $E$ from guinea pig skin. Isolation and partial characterization. J. Biol. Chem. 265: 21971-21978

Lai, T.-S., Slaughter, T.-F., Koropchak, C. M., Haroon, Z. A. and Greenberg, C. S. (1996) C terminal deletion of human tissue transglutaminase enhances magnesium-dependent GTP/ATPase activity. J. Biol. Chem. 271: 31191-31195

Miyachi, Y., Yochimura, N., Suzuki., S., Hamakubo, T., Kanngi, R., Imamura, S. and Murachi., T. (1986) Biochemical demonstration and immunohistochemical localization of calpain in human skin. J. Invest. Dermatol. 86: 346-349

Nakaoka, H., Perez, D. M., Bark, K.-J., Das, T., Husain, A., Misono, K., Im, M.-J. and Graham, R. M. (1994) Gh: a GTP-binding protein with transglutaminase activity and receptor signaling function. Science 264: 1593-1596

Rice, R. H. and Green, H. (1997) The cornified envelope of terminally differentiated human epidermal keratinocytes consists of cross-linked protein. Cell 11: 417-422

Schmidt, R., Michel, S., Shroot, B. and Reichert, U. (1988) Plasma mem-brane transglutaminase and cytosolic transglutaminase form distinct envelope-like structures in transformed human keratinocytes. FEBS Lett. 229: 193-196

Sorimachi, H., Saido, T. C. and Suzuki, K. (1994) New era of calpain research. Discovery of tissue-specific calpains. FEBS Lett. 343: 1-5

Sorimachi, H., Ishiura, S. and Suzuki, K. (1993) A novel tissue-specific calpain species expressed predominantly in the stomach comprises two alternative splicing products with and without $\mathrm{Ca}^{(2+)}$-binding domain. J. Biol. Chem. 268: 19476-19482

Sorimachi, H., Imajoh-Ohmi, S., Emori, Y., Kawasaki, H., Ohno, S., Minami, Y. and Suzuki, K. (1989) Molecular cloning of a novel mammalian calcium-dependent protease distinct from both $\mathrm{m}$-and mu-types. Specific expression of the mRNA in skeletal muscle. J. Biol. Chem. 264: 20106-20111

Steinert, P. M., Kartasova, T. and Marekov, L. N. (1998) Biochemical evidence that small proline-rich proteins and trichohyalin function in epithelia by modulation of the biomechanical properties of their cornified cell envelopes. J. Biol. Chem. 273: 1175811769

Steinert, P. M. and Marekov, L. N. (1995) The proteins elafin, filaggrin, keratin intermediate filaments, loricrin, and small proline-rich proteins 1 and 2 are isodipeptide cross-linked components of the human epidermal cornified cell envelope. J. Biol. Chem. 270: $17702-17711$

Steinert. P. M., Kim, S.-Y., Chung, S.-I. and Marekov, L. N. (1996) The transglutaminase 1 enzyme is variably acylated by myristate and palmitate during differentiation in 
epidermal keratinocytes. J. Biol. Chem. 271: 26242-26250

Steinert, P. M., Chung, S.-I. and Kim, S.-Y. (1996) Inactive zymogen and highly active proteolytically processed membrane-bound forms of the transglutaminase 1 enzyme in human epidermal keratinocytes. Biochem. Biophys. Res. Commun. 221: 101-106

Suzuki, K., Imajoh, S., Emori, Y., Kawasaki, H., Minami, Y. and Ohno, S. (1987) Calcium-activated neutral protease and its endogenous inhibitor. Activation at the cell membrane and biological function. FEBS Lett. 220: 271-277

Thacher, S. M. and Rice, R. H. (1985) Keratinocyte-specific transgluta-minase of cultured human epidermal cells: relation to cross-linked envelope formation and terminal differentiation. Cell 40: 685-695

Wang, K. K. (1990) Developing selective inhibitors of calpain. Trends Pharmacol. Sci. 11: $139-142$
Zhang, H., Guttman, R. P., and Johnson, G. V. W. (1998) Tissue trans-glutaminase is an in situ substrate of calpain: regulation of activity. J. Neurochem. 71: 240-247 